\title{
Escrita e reescrita do gênero textual memória literária: estratégias para melhoria da coesão e da coerência
}

Fabiana Kaodoinski fabikafabi@gmail.com Universidade de Caxias do Sul, Caxias do Sul, Brasil.

Neires Maria Soldatelli Paviani npaviani@ hotmail.com

Universidade de Caxias do Sul, Caxias do Sul, Brasil.

\section{RESUMO}

O presente artigo trata de um estudo de caso que visa a analisar a versão inicial de um texto produzido de acordo com o gênero memória literária, a fim de verificar possibilidades de elaboração de estratégias que auxiliem na melhoria da coesão, da coerência e da concretude textuais no processo de reescrita desse texto, até obter-se uma versão final, conforme proposta de sequência didática. Para tanto, serão utilizados como principais referenciais teóricos Bronckart $(2003,2006)$, Dolz, Noverraz e Schneuwly (2004), Antunes (2005), Koch e Travaglia (2005, 2008), Guedes (2009), Koch (2012), entre outros. A análise buscou gerar contribuições às práticas de produção de gêneros textuais em ambiente formal de aprendizagem, fornecendo subsídios para que o docente possa promover situações que instrumentalizem os alunos a produzirem e a reescreverem seus textos de modo a observar os fatores de coesão e de coerência. A partir do estudo, foi possível perceber que o trabalho, por parte do professor, utilizando gêneros textuais, sequências didáticas, tendo como base conceitos referentes à textualização e ao sentido do texto, em especial a coesão, a coerência e a concretude, mostra-se como um modo de, na aula de língua materna, realizar atividades que ampliam as habilidades dos alunos.

PALAVRAS-CHAVE: Ensino. Gênero. Coesão. Coerência. 


\section{INTRODUÇÃO}

Em variados contextos sociais, nas diversas interações realizadas pelas pessoas, a utilização da escrita é fundamental. Assim, entende-se que é papel da escola, como espaço formal de aprendizagem - e dos professores de todas as áreas -, instrumentalizar os alunos a desenvolverem habilidades para utilizarem a escrita em diferentes situações comunicativas, de forma adequada ao gênero em uso. Nesse sentido, embora haja uma constante preocupação de pesquisadores, tendo em vista a grande quantidade de estudos desenvolvidos acerca do ensino da produção textual, testes em escala internacional referem que, no Brasil, os alunos não possuem um bom desempenho em termos de leitura e de escrita.

Diante desse contexto, entende-se que diversas dificuldades podem estar relacionadas ao ensino da produção de texto, tais como a indefinição de um conteúdo programático; o pouco tempo destinado à prática da escrita na escola, sendo que geralmente ela é delegada ao professor de língua materna; a predominância da realização de análises classificatórias em detrimento da produção textual; e ainda o pouco domínio e/ou aplicação em aula, por parte dos professores, de teorias linguísticas que podem subsidiar o ensino da escrita, em especial, as que enfatizam o trabalho a partir dos gêneros textuais e que entendem o letramento como prática social.

Diante disso, a fundamentação teórica e o estudo de caso presentes neste artigo pretendem mostrar a importância do trabalho a partir dos gêneros textuais, pautado no processo de escrita, reescrita e adequação à situação comunicativa. Busca-se, também, explorar a textualização e o estabelecimento do sentido do texto, bem como apresentar as estratégias aplicadas na experiência com a produção do gênero memória literária, as quais levaram em conta a coesão, a coerência e a concretude, sem perder de vista os usos da linguagem.

Para tanto, apresentar-se-á a aplicação de uma sequência didática contemplando o gênero memória literária. $O$ trabalho foi desenvolvido no ano de 2014, de agosto a outubro, em aulas individuais de Português Instrumental, ministradas semanalmente pelas autoras deste estudo a uma estudante sênior ( identificada pelas iniciais I. I. M. F), em espaço formal de aprendizagem, em um centro cultural situado na cidade de Veranópolis - RS. Essa aluna, há bastante tempo afastada do espaço escolar, durante toda sua vida apreciou expressar-se por meio da escrita de poesias, tendo muitas delas publicadas ou reconhecidas em concursos regionais e até mesmo nacionais.

Pretendendo passar a escrever textos em prosa para publicação, com o intuito de aprimorá-los, buscou auxílio especializado, visando a apropriar-se, principalmente, de estratégias voltadas à melhoria da coesão, da coerência e da concretude textuais, elementos essenciais à textualidade.

Para que a estudante pudesse atingir seu objetivo, as docentes organizaram uma sequência didática, conforme modelo de trabalho de Dolz, Schneuwly e Noverraz (2004), a qual teve como passo inicial a apresentação da situação. Em seguida, foi realizada uma produção inicial. Depois, foram estruturados módulos para estudar o gênero memória literária, bem como para, a partir de apontamentos das docentes, reescrever o texto, melhorando a coesão e a coerência. Posteriormente, chegou-se a uma produção final. 
Nessa perspectiva, acredita-se que este estudo justifica-se pelo fato de a teoria elencada e as análises realizadas fornecerem subsídios que ampliam a reflexão sobre a prática docente relacionada ao ensino da escrita de gêneros literários em prosa, apresentando estratégias cuja aplicação não se limita a textos produzidos em aulas individuais, pois podem, com adaptações, ser exploradas no contexto escolar.

\section{CONCEPÇÃO DE TEXTO E DE GÊNEROS DE TEXTO}

A transformação das ações humanas em textos ocorre, segundo Bronckart, nos processos de semiotização das relações humanas com o meio, como resultado das interações sociais. Sobre isso, o autor acha importante observar "a questão das relações entre o agir em geral e essas formas semiotizadas de agir que são as produções de linguagem". (BRONCKART, 2006, p. 246).

Nessa perspectiva, Bronckart (2003, p. 34) define a linguagem humana como sendo "uma produção interativa associada às atividades sociais" que se organizam "em discursos ou em textos. Sob o efeito da diversificação das atividades não verbais [non llangagières] com as quais esses textos estão em interação, eles mesmos diversificam-se em gêneros". (BRONCKART, 2003, p. 35, grifos do autor), os quais são definidos pelo autor, como sendo:

[...] mecanismos que, no próprio movimento que gera modalidades particulares de oganização dos signos e que chega a formas variadas de 'discurso' (que chamaremos de gêneros de texto) moldam os conhecimentos (objetos, conceitos, estratégias, etc.) dos membros de uma mesma formação social de uma forma particular. (BRONCKART, 2003, p.35, grifos do autor).

Segundo esse autor (2003), há muitos aspectos a serem considerados na produção de um texto, ou seja, na transformação de ação da linguagem em texto, começando pelas condições de produção, às quais nem sempre se tem acesso, mas que materializam seus aspectos externos e internos. Aqueles correspondem aos mundos formais que dão conta das representações desses, interiorizadas pelo agente, podendo ser caracterizáveis e observáveis; e estes, de caráter mais psicológico, subjetivo, social, físico, também, denominados pelo autor de situação efetiva, são responsáveis pela produção. Ou seja, "decorrem das variações que cada produtor individual introduz quando reproduz uma espécie de texto e adapta-o à situação de comunicação particular em que se encontra". (BRONCKART, 2003, p.72).

Nesse sentido, todo texto tem de estar numa relação de interdependência com o contexto; apresentar um modo organizado de seu conteúdo; observar as regras de organização e composição das frases; e atender aos mecanismos de textualização bem como aos enunciativos, com vistas a assegurar-lhe coerência interna.

Em outros termos, e resumidamente, para Bronckart, a questão da linguagem humana entendida como atividade social implica criar e recriar mundos, tendo presente uma interação do verbal e das atividades, efetivando-se com a textualização, por meio de gêneros de textos. 
Por isso, "[...] uma língua natural só pode ser aprendida através das produções verbais, que assumem aspectos muito diversos, principalmente por serem articuladas a situações de comunicação muito diferentes". (BRONCKART, 2003, p. 69).

\section{ENSINO DA ESCRITA POR MEIO DE SEQUÊNCIAS DIDÁTICAS}

De acordo com Dolz, Schneuwly e Noverraz (2004), existe possibilidade de ensinar a escrita e a expressão oral, seja para fins escolares ou não. Para tanto, faz-se necessária a criação de precisos contextos de produção dos textos, bem como de variados e múltiplos exercícios ou atividades.

Os referidos autores (2004, p. 96) propõem o ensino da escrita a partir da sequência didática, definida como "um conjunto de atividades escolares organizadas, de maneira sistemática, em torno de um gênero textual oral ou escrito", objetivando auxiliar o aluno a melhor dominá-lo, ou seja, escrevê-lo de modo mais adequado em determinada situação comunicativa. Sendo assim, através das sequências didáticas, o aprendiz pode ter acesso a novas "práticas de linguagens" ou ainda aperfeiçoar aquelas que ele considera complexas. (DOLZ, SCHNEUWLY E NOVERRAZ, 2004, p. 98).

Conforme o esquema proposto por Dolz, Schneuwly e Noverraz (2004), a sequência didática pode ser organizada de acordo com a descrição abaixo.

O primeiro passo é denominado apresentação da situação. É o momento em que o professor descreve detalhadamente a tarefa a ser realizada pelos alunos, definindo o gênero em estudo e a situação de comunicação, incluindo a finalidade, a forma (oral, escrita, gravada, apresentada por teatro), os participantes e os possíveis destinatários da produção.

Em seguida, passa-se à fase da primeira produção, em que os alunos elaboram um "texto inicial" correspondente ao gênero escolhido para o trabalho. Por meio da análise das produções, o professor pode avaliar as potencialidades e as dificuldades dos aprendizes, a fim de realizar ajustes nos exercícios e/ou nas atividades planejados para a sequência, intervindo, assim, de forma mais adequada.

A próxima etapa corresponde aos módulos, em que, em uma perspectiva social, interacionista e construtivista, são fornecidos aos alunos instrumentos para que possam superar os problemas detectados na produção inicial. Podem ser organizados vários módulos - não há um número definido -, cada qual destinado à melhoria de determinada capacidade necessária para que o aluno domine o gênero proposto. Neles, pode-se trabalhar, por exemplo, com dificuldades de expressão - oral ou escrita -, com a adequação da linguagem, da estrutura do gênero - com comparação entre textos do mesmo gênero ou entre gêneros diversos - e da situação de comunicação. Nesse processo, importa o aluno conseguir desenvolver uma atitude reflexiva diante de sua produção revisando e reescrevendo seu texto - e construir conhecimentos sobre o gênero em estudo.

Na última etapa, realiza-se a produção final. Com ela, o aprendiz coloca em prática aquilo que trabalhou ao longo da sequência e pode ter controle sobre seu processo de aprendizagem, verificando progressos e o que ainda pode fazer, e o 
professor consegue medir a evolução do aluno, realizando, assim, uma avaliação somativa, tendo por base critérios mais objetivos, embora a subjetividade também esteja presente.

De acordo com Dolz, Schneuwly e Noverraz (2004, p. 114), a sequência didática adota uma perspectiva textual, ou seja, leva em conta "os diferentes níveis do processo de elaboração de textos". Desse modo, o trabalho com sequências mostra-se como um complemento a outras abordagens no nível da textualização ao propor atividades que observem, manipulem e analisem as unidades linguísticas.

Posto isso, a seguir, serão descritos de forma mais detalhada elementos de textualidade, em especial a coesão e a coerência, em função de terem sido elementos de análise nos módulos da sequência didática destinada à produção do gênero textual memória literária, conforme será exposto no estudo de caso.

\section{ENTENDENDO A TEXTUALIDADE}

A Linguística Textual, de acordo com Koch (2012, p. 11), tem como objeto de investigação o texto, entendido como "unidade básica de manifestação da linguagem". Assim, os estudos deixam de centrar-se nas palavras ou frases isoladas, levando em conta que é por meio dos textos que o homem se comunica, sendo que muitos fenômenos da linguagem só são entendidos em uma análise realizada no interior do texto. Diante desse contexto, pesquisas foram realizadas para entender de que forma um texto se constitui como tal, ou seja, "que elementos ou fatores são responsáveis pela textualidade", sendo que Beaugrande e Dressler (1981) elegeram sete: a coerência, a coesão, a informatividade, a situacionalidade, a intertextualidade, a intencionalidade e a aceitabilidade. (KOCH, 2012, p. 11).

Entre outros elementos pesquisados pela Linguística Textual, cabe, neste trabalho, evidenciar a contribuição da coesão e da coerência para que ocorra a textualidade. De acordo com Antunes (2005, p. 47), a coesão tem a função de "criar, estabelecer e sinalizar os laços que deixam os vários segmentos do texto ligados, articulados, encadeados". Portanto, para que se possa considerar um texto como coeso, é preciso nele reconhecer que há união entre suas partes, tanto no nível da palavra, quanto do parágrafo, sem haver fragmentos ou ideias soltas. A autora ressalta que isso ocorre para que "se efetive a unidade de sentido das intenções da interação verbal”. (ANTUNES, 2005, p. 49).

Corroborando essa ideia, Kock (2012, p. 15) afirma que a coesão textual é um fenômeno em que, através de alguns mecanismos, "se vai tecendo o 'tecido' (tessitura) do texto". A autora cita Halliday e Hasan (1976), que "apresentam o conceito de coesão textual como um conceito semântico que se refere às relações de sentido existentes no interior do texto e que o definem como um texto." Assim, "a coesão ocorre quando a interpretação de algum elemento no discurso é dependente de outro. Um pressupõe o outro, no sentido de que não pode ser efetivamente decodificado a não ser por recurso ao outro". (HALLIDAY; \& HASAN, 1976, apud KOCK; TRAVAGLIA, 2005, p. 16).

Quanto à função da coesão, Antunes (2005, p. 48) afirma que ela promove "a continuidade do texto e a sequência interligada de suas partes, para que não se 
perca o fio de unidade que garante a sua interpretabilidade". É importante ressaltar que a autora entende que, para apreender o sentido global do texto, não basta conhecer o valor semântico das palavras; é necessário estabelecer relações entre as partes, sendo que a coesão é a responsável pela ligação dessas diferentes unidades. Além disso, elas não ocorrem "simplesmente na superfície da sequência textual. Na verdade, elas sinalizam as ligações conceituais que estão subjacentes a essa superfície", ou seja, no "âmbito do sentido e das intenções pretendidas". (ANTUNES, 2005, p. 48).

De acordo com Halliday e Hassan (1976, apud KOCK, 2012), existem cinco mecanismos de coesão: a referência, que pode ser pessoal, demonstrativa ou comparativa; a substituição nominal, verbal ou frasal; a elipse, que também pode ser nominal, verbal ou frasal; a conjunção, tanto aditiva, quanto adversativa, causal, temporal ou continuativa; e a coesão lexical, caracterizada pela repetição, sinonímia, hiperonímia, uso dos nomes genéricos e colocação.

Cabe avaliar, portanto, cada mecanismo de coesão, buscando sua contribuição para a textualidade. A referencial, de acordo com Koch:

[...] é aquela em que um componente da superfície do texto faz remissão a outro(s) elemento(s) nela presentes ou inferíveis a partir do universo textual. Ao primeiro, denomino forma referencial ou remissiva e ao segundo, elemento de referência ou referente textual. (KOCH, 2012, p. 31).

Ainda sobre essa forma de coesão, a autora $(2012$, p. 31) cita Kallmeyer et. al. (1974), que afirmam que "a relação de referência (ou remissão) não se estabelece apenas entre a forma remissiva e o elemento de referência, mas também entre os contextos que envolvem ambos". Koch ainda salienta que a remissão pode ser anafórica, quando é feita para trás e catafórica quando é feita para frente e que as formas remissivas podem ser gramaticais ou lexicais. As primeiras fornecem ao leitor instruções de conexão, podendo ser: presas, quando compõem-se de artigos, pronomes adjetivos e numerais; ou livres, quando utilizam pronomes pessoais de 3 a pessoa, pronomes substantivos e advérbios pronominais. Já as formas remissivas lexicais podem ser entendidas como "grupos nominais definidos que, além de fornecerem, em grande número de casos, instruções de concordância, contém, também, instruções de sentido, isto é, fazem referência a algo no mundo extralinguístico" (2012, p. 35). Exercem função remissiva lexical expressões ou grupos nominais definidos, nominalizações, expressões sinônimas ou quase sinônimas e hiperônimos ou indicadores de classe. Além disso, a coesão remissiva também pode ser estabelecida por meio da elipse, pronomes substantivos, expressões adverbiais e algumas formas verbais.

Outra forma de coesão, a sequencial, é muito importante no processo de textualização. Também chamada de sequenciação, ela:

[...] diz respeito aos procedimentos linguísticos por meio dos quais estabelecem, entre segmentos do texto (enunciados, partes de enunciados, parágrafos e sequências textuais), diversos tipos de relações semânticas e/ou pragmáticas, à medida que se faz o texto progredir (KOCH; TRAVAGLIA, 2005, p. 53). 
A referida autora entende que é possível haver a progressão textual com ou até mesmo sem elementos recorrentes. A sequenciação frástica não apresenta procedimentos de recorrência estrita, diferentemente da sequenciação parafrástica, em que eles aparecem. $(\mathrm{KOCH}, 2012)$.

Além do estudo da coesão, é importante entender o conceito de coerência e sua relevância para o entendimento dos textos. De acordo com Koch e Travaglia, a coerência:

[...] está diretamente ligada à possibilidade de estabelecer um sentido para o texto, ou seja, ela é o que faz com que o texto faça sentido para os usuários, devendo, portanto, ser entendida como um princípio de interpretabilidade, ligada à inteligibilidade do texto numa situação de comunicação e à capacidade que o receptor tem para calcular o sentido deste texto. Este sentido, evidentemente, deve ser do todo, pois a coerência é global (KOCH; TRAVAGLIA, 2008, p. 21).

As regras de coerência regulam o modo como a sequência do texto se constitui ou se organiza, ajudando, portanto, a evitar incoerências (ANTUNES, 2005). Quanto a isso, para Koch e Travaglia (2008, p. 51), incoerências podem surgir em função do mau uso dos elementos linguísticos de coesão. Por outro lado, sendo a coesão apenas um dos fatores de coerência, é comum existir textos que possuem coesão entre as partes, mas que neles não é possível ser estabelecida uma unidade de sentido. Para que isso ocorra, os referidos autores (citando Bernárdez, 1982) afirmam que é preciso levar em conta todo o processo de constituição desse texto, "desde a intenção comunicativa do produtor (falante/escritor) até as estruturas linguísticas em que se manifesta finalmente essa intenção". (KOCH; TRAVAGLIA, 2008, p. 51).

Além disso, o leitor de um texto sempre acaba realizando um processo de busca da coerência, através de diversos recursos, mesmo que aquilo com o qual se depara pareça absurdo. Segundo Koch e Travaglia (2008), isso ocorre porque, em uma situação comunicativa, os que participam da interação sempre estão em um processo de cooperação mútua, sendo que até incoerências podem ser compreendidas pelo leitor como propositais. Para tais autores $(2008$, p. 71), fatores diversos contribuem para a construção da coerência do texto: "linguísticos, discursivos, cognitivos, culturais e interacionais". Em especial, cabe aqui destacar os elementos linguísticos, que dão pistas para que os conhecimentos armazenados na memória sejam ativados. Eles ainda "constituem um ponto de partida para a elaboração de inferências e ajudam a captar a orientação argumentativa dos enunciados que compõe o texto". (KOCH; TRAVAGLIA, 2008, p. 71).

O conhecimento de mundo, por sua vez, estabelece a coerência pelo fato de que ele é um referencial necessário para atribuir sentido ao que se lê. De acordo com Koch e Travaglia (2008, p. 72), o texto parecerá sem coerência, ou será difícil de entender seu sentido, se trouxer um conteúdo extremamente desconhecido ao leitor. Assim, as vivências e experiências constituem o conhecimento de mundo, o qual é armazenado em blocos, denominados modelos cognitivos, que se subdividem em frames, esquemas, planos, scripts e superestruturas, ou esquemas textuais. 
Esse tipo de conhecimento é fundamental para estabelecer o sentido de um texto, pois permite que processos cruciais para a compreensão sejam realizados, como "a construção de um mundo textual", "o estabelecimento da continuidade do sentido" e "a construção da macroestrutura" (KOCH; TRAVAGLIA, 2005, p. 60).

O conhecimento compartilhado, por sua vez, estabelece a coerência do texto por ajudar o leitor a suprir as lacunas percebidas. Isso ocorre em função de que ele fará inferências e entenderá a informação nova a partir daquela que conheceu anteriormente: "se um texto contivesse apenas informação nova, seria ininteligível, pois faltariam ao receptor as bases (âncoras) a partir das quais ele poderia proceder ao processamento cognitivo do texto". (KOCH; TRAVAGLIA, 2008, p. 77). Os referidos autores afirmam que, por outro lado, o texto seria redundante se fosse composto apenas por informações dadas.Ademais, de acordo com Koch e Travaglia (2008, p. 79), a inferência, "operação pela qual, utilizando seu conhecimento de mundo, o receptor de um texto estabelece uma relação não explícita entre dois elementos deste texto que ele busca compreender e interpretar", permite que os sentidos emanem do texto sem que tudo esteja explícito. Caso contrário, os dados precisariam ser extensos para conseguirem explicitar o que se pretende (KOCH; TRAVAGLIA, 2008).

Também para estabelecer a coerência, os fatores de contextualização, como data, local, timbre, assinatura e elementos gráficos, de acordo com Marcuschi (1983, apud KOCK; TRAVAGLIA, 2008, p. 81), "ajudam a situar o texto e, portanto, a estabelecer-Ihe a coerência". Da mesma forma, a situacionalidade - que envolve "o lugar e o momento da comunicação, as imagens recíprocas que os interlocutores fazem uns dos outros, os papéis que desempenham, seus pontos de vista, o objetivo da comunicação" - exerce tal função, pois um texto pode ser coerente em uma situação e não ser em outra, porque existe, em cada caso, um adequação do texto à situação de comunicação.

Destaca-se também a informatividade, que tem relação com a previsibilidade das informações trazidas pelo texto. Tal característica é determinante no que se refere à seleção e ao arranjo de possibilidades para distribuir a informação no texto, de forma que o leitor possa encontrar a coerência de modo mais fácil ou mais difícil (KOCH; TRAVAGLIA, 2008).

A focalização também interfere no processo de construção da coerência, pois no processamento do texto, é importante que o foco do produtor e do receptor sejam semelhantes, para que o leitor não faça uma leitura de forma totalmente diferente daquela pretendida pelo produtor. ( $\mathrm{KOCH}$; TRAVAGLIA, 2008).

A intertextualidade, em que há repetição em determinado texto de enunciados ou trechos de outros textos, interfere na coerência pelo fato de que, se o texto-fonte não for reconhecido, há prejuízo na construção do sentido do que está sendo lido. (KOCH; TRAVAGLIA, 2008, p. 92).

A intencionalidade é definida por Kock e Travaglia (2008, p. 97) como o "modo como os emissores usam textos para perseguir e realizar suas intenções, produzindo, para tanto, textos adequados à obtenção dos efeitos desejados". Ela também permite ao leitor a construção de determinada leitura, guiando-se pela forma como o texto está estruturado linguisticamente. Assim, as marcas linguísticas propostas pelo produtor do texto conferem pistas para que o leitor construa o efeito desejado pelo primeiro. 
Além disso, a aceitabilidade constrói a coerência à medida que o leitor que encontra problemas no entendimento do texto dá a ele a interpretação que lhe parece aceitável. Já a consistência e relevância são fatores de coerência na produção discursiva, pois os tópicos em destaque deverão ser relevantes e consistentes para o desenvolvimento de um tópico mais amplo $(\mathrm{KOCH}$; TRAVAGLIA, 2008).

Diante do que foi discorrido sobre a coerência, cabe destacar, conforme Koch e Travaglia (2008, p. 100), que "ela não é apenas um traço ou uma propriedade do texto em si, mas sim que ela se constrói na interação entre o texto e seus usuários". Sendo assim, cabe ao leitor buscar um sentido para o que está lendo/ouvindo.

Assim, afirma-se que, sabendo a definição de coesão e coerência, é possível estabelecer a forma como elas se relacionam. Kock e Travaglia (2008, p. 47) citam Benárdez (1892), que afirma haver um processo de "mão dupla" quando se pensa a relação entre coesão e coerência:

[...] na produção do texto se vai da coerência (profunda), a partir da intenção comunicativa, do pragmático até o sintático, ao superficial e linear da coesão e na compreensão do texto se percorre o caminho inverso das pistas linguísticas na superfície do texto à coerência profunda (KOCH; TRAVAGLIA, 2008, p. 47).

Diante do exposto, foi possível perceber que a coesão e a coerência precisam ser observadas no momento de escrever um texto, levando em conta a intenção do autor em produzir determinado sentido. Outra característica importante a ser observada nesse processo é a concretude, a qual, segundo Guedes (2009, p. 59), "garante que a mensagem seja expressa com precisão para que não restem dúvidas no leitor a respeito dos sentidos e valores que o autor atribuiu aos recursos expressivos com que a constituiu". Logo, é mais fácil para o leitor construir a coerência de um texto se este mostrar-se concreto.

$\mathrm{Na}$ sequência, para materializar a descrição exposta, será realizada a explanação de um estudo de caso envolvendo escrita e reescrita do gênero textual memória literária a fim de melhorar a coesão, a coerência e a concretude do texto.

\section{ESTUDO DE CASO: ESCRITA E REESCRITA DO GÊNERO MEMÓRIA LITERÁRIA, COM OBSERVAÇÃO DA COESÃO, DA COERÊNCIA E DA CONCRETUDE NA PRODUÇÃO TEXTUAL DO ALUNO}

O texto a ser analisado foi produzido em uma situação formal de aprendizagem, com supervisão das docentes, que se revezaram na tarefa, discutindo em conjunto as ações realizadas. A produtora do texto, aqui denominada aluna ou autora, dizia gostar muito de escrever, principalmente poesias, tendo ganhado vários concursos literários de poesia e recebido outras premiações por suas produções. Apresentou, em seus escritos realizados antes deste trabalho, bom domínio gramatical e uma rica linguagem literária, mas certa dificuldade deem tornar suas produções em prosa, principalmente as que envolviam relatos, mais coesas e concretas, o que motivou as docentes a criar 
estratégias para melhorar essa situação através da elaboração de uma sequência didática, conforme proposta de Dolz, Schneuwly e Noverraz (2004).

Com a sequência organizada, foi disponibilizadoacompanhamento individualizado à aluna, objetivando auxiliá-la a ter melhor domínio do gênero de texto memória literária. Para tanto, foram lidas algumas memórias, sendo que, após o passo de apresentação da situação, definido o contexto de produção do gênero, aluna realizou sua produção inicial, já explicando que pretendia inserir relatos históricos em seu texto, mas que sentia certa dificuldade em explicar, através da escrita, os fatos ocorridos, de modo que a coerência fosse estabelecida pelo leitor da forma pretendida pela produtora.

Quanto à memória literária, de acordo com Köche, Marinello e Boff (2012), é um gênero que realiza um registro de fatos do passado da vida do autor a partir de suas lembranças pessoais. Geralmente, esses acontecimentos foram esquecidos, sendo narrados do modo como quem escreve vai lembrando-se deles. Embora apresente um caráter histórico, na memória literária, há o emprego da linguagem literária, a qual visa a despertar as emoções do leitor, sendo que esse gênero pode ser escrito a partir de um depoimento ou da vivência pessoal do autor.

Após receber a primeira versão do texto, as docentes detectaram aspectos textuais que poderiam ser revistos ou ampliados para que a coerência ficasse estabelecida e a coesão melhorada.

Foram planejados três módulos para que se chegasse a uma versão final do texto, envolvendo o estudo: do gênero memória literária; da coesão; da coerência; de aspectos relacionados ao uso da linguagem, como: pontuação, devido à mudança de sentido que o emprego da vírgula pode gerar; e de pronomes, para evitar a repetição de termos. Além disso, foram fornecidos exemplos de hipônimos e hiperônimos, referenciação por meio de sinônimos, entre outros como estratégia para tornar o texto mais coeso. Falou-se ainda sobre as elipses e outros usos da linguagem. Assim, a partir dos apontamentos (explicados a seguir), foram organizados módulos em que o texto foi sendo reelaborado pela aluna, em vários momentos, até que se chegou à produção final, também exposta na sequência.

Abaixo, transcrevemos a primeira versão da memória literária produzida ${ }^{1}$.

\section{Um simples toque}

I. I. M. F.

Moro numa pequena cidade de ruas largas e floridas, na região da serra, no interior do Rio Grande do Sul. A maioria das pessoas que vivem aqui é descendente de imigrantes italianos e o seu desejo, assim como o meu, é progredir sempre mais.

Depois da revolução industrial, com o aparecimento das máquinas e com o aparecimento da tecnologia, creio que nos deixamos influenciar com isso, visto que mudamos o jeito de vestir, de falar, de trabalhar, de estudar, de morar. Desde que tive acesso aos eletrodomésticos, chamo alguns deles de "varinhas mágicas", 
pois eles ajudam a ganhar tempo e, nisto, são especialistas, pois, basta um simples toque para que se desdobrem em suas ocupações.

Foi numa tarde de verão que, com um toque apenas, ganhei um presente delicado e, como num sonho, fui parar, junto à janela, nos braços do meu nono (avô). E, nessa tela improvisada, repassei, como se fosse um filme, algumas mudanças vividas e guardadas alma adentro.

Eu tinha em torno de sete anos e ainda não sabia o Ato de Contrição. Lembrei-me que usava um vestido vermelho de lã e tremia por inteiro, enquanto passava, com meus pais, em frente às casas que exibiam nos seus telhados, chaminés fumacentas. Era domingo de manhã. Estava frio na rua e somente os homens usavam calças compridas. Morta de frio, só me aqueci quando entrei na igreja.

Lá dentro, não conseguia entender o padre que, de quando em quando, virava-se, abria os braços e pronunciava palavras complicadas para dois meninos de vermelho e branco. Num dado momento, vi que o padre entrou num tal de púlpito e logo começou a esbravejar para as pessoas, que sentadas e com o terço na mão, ficaram mais sérias do que antes. E eu chorei, sentindo-me culpada de não-sei-o-que. A missa, até na década de cinquenta do século passado, parecia ser só do padre e dos coroinhas.

O tempo fechava com frequência para mim, principalmente, quando eu fazia perguntas ou tentava dar minha opinião. Mandavam-me calar a boca, porque, criança não sabia nada e não devia falar sobre certos assuntos. Então, embaraçada, escondia-me. Não era a toa que, seguidamente, perdia o Ato de Contrição e ganhava um castigo envergonhado no corredor principal da Igreja Matriz. Em casa, também era castigada por não aprendê-lo no dialeto italiano.

Algum tempo mais tarde, fiquei intrigada quando percebi que as mulheres casadas usavam véu preto, as moças, branco e todas, na igreja, ficavam separadas dos homens e que, às vezes, uma que outra desmaiava pelo jejum desde a meia-noite. Perguntava por que as mulheres tinham que cobrir a cabeça e ninguém me dava resposta.

Todos os anos, no entanto, esperava pelo Natal, que me trazia a missa do galo e o presépio, onde as figuras se movimentavam e encantavam gente grande e pequena, que usava roupas novas e festejava, com devoção, o Deus Menino.

Logo percebi mudanças. Percebi que todo mundo, ao mesmo tempo, resolvera, ao mesmo tempo, pensar diferente. E eu imaginava, serem brincadeiras do tempo. Só que o tempo não estava brincando e muita gente confundia-se.

Mas, o tempo, culpado ou não, parecia estar de mangas arregaçadas, pois, na igreja, o púlpito desapareceu; o padre não ficava mais de costas para a celebração; a missa não era mais em latim; as pessoas, meio relutantes, iam deixando seu terço em casa; os coroinhas iam brincar para lá e para cá e as mulheres, um tanto tímidas, passaram a cuidar de sua cabeça.

Eram nos telhados, porém, que ocorriam mudanças significativas. As chaminés, meio preguiçosas, ganharam companhia: as antenas de TV. Daí em diante, pouca gente se lembrava do que era o jejum. 
Durante meu perscrutar o passado, reparei que em qualquer tempo, as pessoas mudam o mundo. Realmente, mudar faz parte do ser humano, tanto que há muitos anos atrás meus antepassados e muitos outros italianos, mudaram-se para esta terra. Aqui vieram far la América (fazer a América). Aqui vieram para encontrar a cucagna (a abundância). Assim falava meu nono Giovani que aqui chegara, moço ainda, com seus pais e irmãos nos fins do século XIX.

Comovida, revi aqueles momentos em que o nono, com mil gestos, com voz potente, numa linguagem toda sua, dava ideia de um quadro surrealista quando me contava sobre a dificuldades que tiveram na américa, das bênçãos e do desânimo, das preces e da saudade, dos experimentos e dos recomeços, das conquistas e também do trabalho, que se tornara a chave para um futuro promissor.

Lembrei-me que meu nono ficara com o olhar iluminado ao falar de sua história de vida e que ele olhara, ora para o nada, ora para a parede onde estavam alguns quadros, trazidos da Itália. Lembrei também que nós dois permanecemos, por um tempo, assim calados, um ao lado do outro, analisando nossas memórias e mudanças. Logo depois nos abraçamos, cheios de ternura, multiplicando e dividindo entre nós a força da esperança...

Logo dei-me conta de que a música, o presente delicado, chegara ao final e eu sorri.

Hoje, no meu entardecer, ainda me aqueço na igreja, cantando nas celebrações, porém, ocupo-me me transformar, com a ajuda, é claro, das minhas ajudantes mágicas, porque a mudança, quase sempre, está ligada ao progresso e este é impulsionado por um simples toque de necessidade ou de desejo.

Nas contas do meu tempo, eu penso que depois de tantos anos da imigração, depois de tanto tempo de laços e traços ítalo-brasileiros, esta cidade é o curriculum vitae de um povo, é o seu corpo e sua alma num jeito de compromisso. Mas, por causa de muitos toques, nada tão simples, das pessoas a vida não segue seu curso naturalmente.

\section{RESULTADOS E ANÁLISE: ALGUNS APONTAMENTOS REALIZADOS NA PRIMEIRA VERSÃO DO TEXTO}

Analisando a primeira versão do texto, pareceu-nos que havia adequação da linguagem em relação ao público-alvo, bem como ele poderia ser considerado pertencente ao gênero memória literária, conforme foi proposto à aluna que escrevesse. Percebemos, porém, alguns aspectos textuais que poderiam tornar a escrita mais adequada, coesa e coerente, os quais serão expostos a seguir.

O segundo parágrafo, transcrito abaixo, poderia se tornar mais coeso se a escritora relacionasse melhor o trecho que fala das mudanças após a Revolução Industrial (mudar o jeito de morar) com a seguinte oração, no mesmo parágrafo: "Desde que tive acesso...". Sugerimos que ela utilizasse um conector, ou um termo que retomasse a linha temática. Outra opção seria substituir "influenciar com isso" por "pelas facilidades que ela trouxe". O pronome ela parece retomar melhor o referente, e o emprego de as praticidades dão ao parágrafo mais coerência, uma vez que a relação estabelecida, logo após, entre "varinha mágica" 
e "eletrodomésticos" é de praticidade. Percebe-se a repetição da palavra "aparecimento", a qual pode ser substituída ou retirada.

Observa-se que o termo "deles" foi bem empregado, pois retoma eletrodomésticos. Já o "eles", em seguida, pode ser eliminado sem prejuízo de sentido, evitando uma repetição desnecessária. Após, a aluna utilizou "nisto" para retomar uma ideia que já havia sido posta. Sugerimos a troca por "nisso", por ser um elemento anafórico.

A seguir, são transcritas as duas versões deste parágrafo (a inicial e a final), podendo ser verificadas as mudanças efetivadas na reescrita realizada com base nos apontamentos sugeridos:

Primeira versão do trecho:

Depois da revolução industrial, com o aparecimento das máquinas e com o aparecimento da tecnologia, creio que nos deixamos influenciar com isso, visto que mudamos o jeito de vestir, de falar, de trabalhar, de estudar, de morar. Desde que tive acesso aos eletrodomésticos, chamo alguns deles de "varinhas mágicas", pois eles ajudam a ganhar tempo e, nisto, são especialistas, pois, basta um simples toque para que se desdobrem em suas ocupações.

Versão final do trecho (organizada em dois parágrafos):

Estive pensando que a Revolução Industrial, fazendo aparecer as máquinas e trazendo mudanças tecnológicas no processo produtivo, impulsionou o progresso, também verificado através da história dos homens, com avanços nos setores da sociedade em que eles atuaram, como no trabalho, na religião, na educação, na saúde, na política e até na família.

Noto que, no meu dia a dia, também aconteceram pequenas mudanças. Na minha casa, por exemplo, várias coisas mudaram. Desde que tive acesso aos eletrodomésticos, chamo-os de "varinhas mágicas". Percebi que eles me ajudam a organizar melhor os meus afazeres e a ganhar mais tempo e, nisso, são especialistas, pois, às vezes, basta um simples toque, um simples gesto de apertar um botão para que essas máquinas se desdobrem em suas ocupações.

Nota-se que a tentativa de ampliar a concretude da noção de que as máquinas e as tecnologias influenciaram as pessoas tornou a ideia mais coerente. A autora parte da explanação de mudanças globais fomentadas pela tecnologia, evidenciadas por meio de exemplos, chegando a alterações geradas em seu dia a dia. Ademais, explicar o que, no texto, significa o "simples toque" é importante para o leitor constituir sentido referente a essa expressão.

No terceiro parágrafo, foi numa tarde de verão que, com um toque apenas, ganhei um presente delicado e, como num sonho, fui parar, junto à janela, nos braços do meu nono (avô). E, nessa tela improvisada, repassei, como se fosse um filme, algumas mudanças vividas e guardadas alma adentro [...], chama a atenção o fato de a autora utilizar a oração "foi numa tarde de verão que, com um toque apenas, ganhei..." (segundo a autora, esse "toque" referia-se ao toque no rádio, o qual tocou uma música). Nós, professoras, após ler todo o texto, não conseguimos construir esse sentido; achamos vago. Como o leitor, através das pistas do texto, constrói a coerência, interpretamos, por não ter outra marca 
textual, que houve um estalo de dedos. Orientamos a aluna, nos módulos da sequência didática, a explicitar o que seria esse "toque" para o leitor poder construir a coerência. Também explicamos sobre a importância de tornar alguns dados do texto mais concretos e mais ligados entre si (coesão), pois, conforme explicamos a ela, a coesão é um fator importante para o estabelecimento da coerência e isso se mostrava fundamental para que ela atingisse seus propósitos nessa situação comunicativa. Após reescrito, o trecho ficou desta forma: Foi numa tarde de verão que, com um toque apenas no aparelho de som, ganhei uma delicada música de presente e, como num sonho, fui parar nos braços do meu nonno (avô). Absorta, repassei, nessa tela improvisada, como se fosse um filme, algumas mudanças vividas e guardadas alma adentro:

Adiante, no quarto parágrafo, a aluna começa a contar suas memórias de infância e menciona o fato de não saber rezar o ato de contrição, sem explicar de que forma isso poderia influenciar a história. Do mesmo modo, o termo "tremia por inteiro" permitiu que fizéssemos duas inferências: que a autora podia estar tremendo de medo, ou de frio: Eu tinha em torno de sete anos e ainda não sabia o Ato de Contrição. Lembrei-me que usava um vestido vermelho de lã e tremia por inteiro, enquanto passava, com meus pais, em frente às casas que exibiam nos seus telhados, chaminés fumacentas. Era domingo de manhã. Estava frio na rua e somente os homens usavam calças compridas. Morta de frio, só me aqueci quando entrei na igreja.

Outro detalhe interessante pode ser percebido quando ela ressalta que "só os homens usavam calças". Em nossa análise, o enunciado estava confuso, pois, como o referente estava distante, não dava para entender se as calças foram mencionadas por: esquentarem o corpo dos homens, sendo que a personagem, por ser menina não podia usá-las e, por isso, acabava passando frio; ou se foi registrado, enquanto dado histórico, o fato de somente os homens, na época, poderem usar calças. Nesse caso, poderíamos nos questionar: qual a relevância do comentário no contexto, já que não foi retomado? Diante disso, percebe-se que o leitor, a muito custo, constrói a referenciação no final do parágrafo, quando, mesmo sem nenhum conector, a escritora menciona que só se aqueceu quando entrou na igreja. Assim, a falta de explicitação da conexão entre as ideias, principalmente de causa e de consequência, bem como a dificuldade de percepção da ligação temática acabou dificultando a compreensão.

Com a reescrita, obteve-se: Lembrei-me de que tinha sete anos e, usando um vestido vermelho de lã, tremia de bater o queixo enquanto passava, com meus pais, em frente às casas que exibiam nos seus telhados chaminés fumacentas. Naquela manhã de domingo, quando fomos à missa, a temperatura estava muito baixa. Morta de frio, só comecei a me aquecer no momento em que entrei na Igreja e senti o calor emanado pelas pessoas.

No quinto parágrafo, sentimos falta de um elemento coesivo, um conector que pudesse unir a informação de que "a missa, até na década de cinquenta do século passado, parecia ser só do padre e dos coroinhas" com o que foi dito anteriormente: Lá dentro, não conseguia entender o padre que, de quando em quando, virava-se, abria os braços e pronunciava palavras complicadas para dois meninos de vermelho e branco. Num dado momento, vi que o padre entrou num tal de púlpito e logo começou a esbravejar para as pessoas, que sentadas e com o terço na mão, ficaram mais sérias do que antes. E eu chorei, sentindo-me culpada 
de não-sei-o-que. A missa, até na década de cinquenta do século passado, parecia ser só do padre e dos coroinhas.

Essa parte foi reescrita da seguinte forma:

Lá dentro, não conseguia entender o padre que, de vez em quando, virava-se, abria os braços e pronunciava palavras complicadas para dois meninos de vermelho e branco. Num dado momento, vi que ele entrou num tal de púlpito e logo começou a esbravejar para as pessoas, que, sentadas e com o terço nas mãos, ficaram muito mais carrancudas - os adultos estavam, quase sempre, com a fisionomia carregada. E eu chorei, sentindo-me culpada de não-sei-o-quê.

Comecei a refletir sobre o fato de que a missa, até na década de cinquenta do século passado, era bem diferente de como é nos dias atuais, em que as pessoas "participam" da celebração. Naquele tempo, quem rezava era o padre e os que respondiam eram os coroinhas. As pessoas, simplesmente, "assistiam" à missa rezando o terço. O sexto parágrafo, por sua vez, parece iniciar um assunto totalmente diferente dos abordados anteriormente: $\boldsymbol{O}$ tempo fechava com frequência para mim, principalmente, quando eu fazia perguntas ou tentava dar minha opinião. Isso gerou a falta de ligação temática. Foi reescrito da seguinte forma: $A$ falta de sintonia entre o padre e os fieis, na igreja, parecia repetir-se na minha casa. Quando eu fazia perguntas ou tentava dar minha opinião sobre qualquer assunto, mandavam-me calar a boca

Ademais, fala-se do ato de contrição novamente, mas falta estabelecer uma relação entre o que passou a ser dito com o que foi posto antes, bem como explicitar ao leitor o porquê da utilização dos comentários sobre ela não poder dar sua opinião: Então, embaraçada, escondia-me. Não era a toa que, seguidamente, perdia o Ato de Contrição e ganhava um castigo envergonhado no corredor principal da Igreja Matriz. Em casa, também era castigada por não aprendê-lo no dialeto italiano.

Parece faltar concretude. Nesse ponto do texto, o leitor fica confuso, pois não sabe se o que a autora conta no sexto parágrafo tem relação com a história que ela vinha contando ou é um aspecto da infância que ela quer ressaltar. Se assim for, por que quer evidenciar (já que no texto não fica claro)?

Ao reelaborar o trecho, obteve-se:

Recordei ainda que ia tristonha ao Catecismo porque sempre ficava de castigo no corredor principal da Igreja Matriz. É que eu não conseguia aprender em português o Ato de Contrição, visto que, em casa, ensinavam-me em dialeto vêneto. E tanto num lugar quanto no outro, na hora da "sabatina", eu fazia confusão, misturando os dois jeitos de dizê-lo. Por isso, era castigada em casa também. Lembro-me de que, antigamente, a criança fazia a Primeira Comunhão com sete anos e, até antes disso, ela precisava dizer o Ato de Contrição "de cor e salteado". Eu estava atrasada, portanto.

Logo depois, a autora retoma o contexto da igreja, mostrando suas percepções sobre a forma como as mulheres se vestiam e logo passa a escrever sobre o Natal. A partir desse momento, pareceu-nos que o texto ficou falando deassuntos diferentes: Percebe-se, que ela fala das mudanças - "Logo percebi mudanças" -, que estão, de certa forma, relacionadas ao início do texto. Mas, com tanta informação, não fica claro. Pedimos para ela fazer um paralelo entre as informações apresentadas, relacionando uma com a outra, dando uma sequência 
e explicitando a relação entre as partes do texto, até para que o leitor entendesse a relevância de cada informação. Em cada parte, ao ler, era preciso fazer muitas inferências, só que elas direcionavam a determinadas interpretações que lá no final nem sempre se confirmavam, tanto que nós, enquanto leitoras, entendemos, na primeira leitura, muitos dados de forma contrária ao que a aluna nos disse, depois, ter "tentado exprimir". Então, propomos a ela a reorganização da unidade temática, para o leitor construir uma linha lógica de raciocínio e o sentido do todo. Assim foi o resultado:

Hoje, o Catecismo chama-se Catequese; as crianças fazem a Primeira Comunhão com mais idade; elas não ficam mais de castigo e a maioria delas manda e desmanda, manipulando seus próprios pais, como se eles fossem agora os fantoches. Muitas delas, depois que finalizam as etapas da Catequese, dão um profundo suspiro e traçam um ponto final...

Recordei que comigo não aconteceu isso, já que continuei a frequentar a Igreja depois da minha Primeira Comunhão. Lembrei-me de que, naquela época, as mulheres casadas usavam véu preto, as moças, branco, e todas, nesse lugar sagrado, ficavam separadas dos homens e, às vezes, alguma delas desmaiava pelo jejum desde a meia-noite. Eu perguntava por que as mulheres tinham que cobrir a cabeça e ninguém me respondia. Então ficava triste por não saber o porquê e também pelo descaso com que era tratada.

Sobre muitas coisas, continuei não entendendo o motivo de serem como eram $[\ldots]$

Quanto à conclusão, reforçamos a necessidade de retomar a informação dada, bem como de perceber a importância do tema/rema, trabalhado nos módulos de aperfeiçoamento do texto.

A seguir, apresentamos como ficou a produção final realizada a partir de vários processos de reescrita do gênero, de acordo com os comentários feitos, expostos anteriormente.

\section{Um simples toque}

I. I. M. F.

Moro em uma pequena cidade de ruas largas e floridas, na região da serra, no interior do Rio Grande do Sul. A maioria das pessoas que vive aqui é descendente de imigrantes italianos e o seu desejo, assim como o meu, é progredir sempre mais. Vale dizer que progredir é avançar, é promover o desenvolvimento, é mudar a vida para melhor. Progredir é fazer tudo o que se escolheu fazer da melhor maneira e sem prejudicar quem quer que seja.

Estive pensando que a Revolução Industrial, fazendo aparecer as máquinas e trazendo mudanças tecnológicas no processo produtivo, impulsionou o progresso, também verificado através da história dos homens, com avanços nos setores da sociedade em que eles atuaram, como no trabalho, na religião, na educação, na saúde, na política e até na família.

Noto que, no meu dia a dia, também aconteceram pequenas mudanças. Na minha casa, por exemplo, várias coisas mudaram. Desde que tive acesso aos eletrodomésticos, chamo-os de "varinhas mágicas". Percebi que eles me ajudam a organizar melhor os meus afazeres e a ganhar mais tempo e, nisso, são 
especialistas, pois, às vezes, basta um simples toque, um simples gesto de apertar um botão para que essas máquinas se desdobrem em suas ocupações.

Foi numa tarde de verão que, com um toque apenas no aparelho de som, ganhei uma delicada música de presente e, como num sonho, fui parar nos braços do meu nonno (avô). Absorta, repassei nessa tela improvisada, como se fosse um filme, algumas mudanças vividas e guardadas alma adentro:

Lembrei-me de que tinha sete anos e, usando um vestido vermelho de lã, tremia de bater o queixo enquanto passava, com meus pais, em frente às casas que exibiam nos seus telhados chaminés fumacentas. Naquela manhã de domingo, quando fomos à missa, a temperatura estava muito baixa. Morta de frio, só comecei a me aquecer no momento em que entrei na lgreja e senti o calor emanado pelas pessoas.

Lá dentro, não conseguia entender o padre que, de vez em quando, virava-se, abria os braços e pronunciava palavras complicadas para dois meninos de vermelho e branco. Num dado momento, vi que ele entrou num tal de púlpito $e$ logo começou a esbravejar para as pessoas, que, sentadas e com o terço nas mãos, ficaram muito mais carrancudas - os adultos estavam, quase sempre, com a fisionomia carregada. E eu chorei, sentindo-me culpada de não-sei-o-quê.

Comecei a refletir sobre o fato de que a missa, até na década de cinquenta do século passado, era bem diferente de como é nos dias atuais, em que as pessoas "participam" da celebração. Naquele tempo, quem rezava era o padre e os que respondiam eram os coroinhas. As pessoas, simplesmente, "assistiam" à missa rezando o terço.

A falta de sintonia entre o padre e os fieis, na igreja, parecia repetir-se na minha casa. Quando eu fazia perguntas ou tentava dar minha opinião sobre qualquer assunto, mandavam-me calar a boca, porque criança não sabia nada $e$ não devia falar sobre assunto nenhum. Naquela época, a criança não tinha vez em nada. Ela era dominada e, se não obedecesse, apanhava de chinelo, de vara de marmelo ou de cinto. Para mim, ela era manipulada como um fantoche.

Recordei ainda que ia tristonha ao Catecismo porque sempre ficava de castigo no corredor principal da Igreja Matriz. É que eu não conseguia aprender em português o Ato de Contrição, visto que, em casa, ensinavam-me em dialeto vêneto. E tanto num lugar quanto no outro, na hora da "sabatina", eu fazia confusão, misturando os dois jeitos de dizê-lo. Por isso, era castigada em casa também. Lembro-me de que, antigamente, a criança fazia a Primeira Comunhão com sete anos e, até antes disso, ela precisava dizer o Ato de Contrição "de cor e salteado". Eu estava atrasada, portanto.

Hoje, o Catecismo chama-se Catequese; as crianças fazem a Primeira Comunhão com mais idade; elas não ficam mais de castigo e a maioria delas manda e desmanda, manipulando seus próprios pais, como se eles fossem agora os fantoches. Muitas delas, depois que finalizam as etapas da Catequese, dão um profundo suspiro e traçam um ponto final...

Recordei que comigo não aconteceu isso, já que continuei a frequentar a Igreja depois da minha Primeira Comunhão. Lembrei-me de que, naquela época, as mulheres casadas usavam véu preto, as moças, branco, e todas, nesse lugar sagrado, ficavam separadas dos homens e, às vezes, alguma delas desmaiava pelo jejum desde a meia-noite. Eu perguntava por que as mulheres tinham que 
cobrir a cabeça e ninguém me respondia. Então ficava triste por não saber o porquê e também pelo descaso com que era tratada.

Sobre muitas coisas, continuei não entendendo o motivo de serem como eram, mas, pelo menos, hoje, sei o porquê daquela vestimenta feminina: conforme nos diz a Bíblia, o Apóstolo Paulo, em sua l Carta aos Coríntios, determinou que a mulher, na Igreja, deveria fazer uso do véu para demonstrar sua honra e dignidade e também para mostrar sua subordinação ao marido. Essa prática, recomendada apenas para a Igreja de Corinto - por causa dos seus problemas doutrinários e de seus costumes - tornou-se obrigatória em toda a Igreja Católica até a realização do Concílio Ecumênico Vaticano II, na década de sessenta do século XX. Depois disso, por tradição, somente as noivas fazem uso do véu, na ocasião de seu casamento. Pelo menos é assim aqui no Brasil, entre os católicos.

Lembrei-me ainda de que, todos os anos, esperava, feliz, pelo Natal, que me trazia a missa do galo e o presépio, em que as figuras movimentavam-se e encantavam gente grande e pequena, que usavam roupas novas e festejavam, com devoção, o Deus Menino.

Eu percebi, à medida que o tempo passava, que quase todo mundo, ao mesmo tempo, passou a agir de maneira diferente. E eu imaginava que eram brincadeiras do tempo. Só que o tempo não estava brincando e, assim, muita gente confundia-se.

Mas o tempo, culpado ou não, parecia estar de mangas arregaçadas. Na igreja, o púlpito desapareceu; o padre não ficava mais de costas para a celebração; a missa não era mais em latim; as pessoas, meio relutantes, iam deixando seu terço em casa; os coroinhas iam brincar pra cá e pra lá e as mulheres começaram, timidamente, a cuidar de sua cabeça, tanto por dentro, quanto por fora e passaram, na igreja, a sentar-se ao lado dos homens.

Era nos telhados, porém, que ocorriam mudanças significativas. As chaminés, meio preguiçosas, ganhavam influente companhia: as antenas de televisão. Daí em diante, pouca gente ainda se lembrava do que era o jejum.

Durante meu ato de perscrutar o passado, reparei que, em qualquer tempo, as pessoas mudam o mundo. Realmente, mudar faz parte do ser humano, tanto que, há muitos anos atrás, meus antepassados e muitos outros italianos, mudaram-se para esta terra. Vieram far la Merica (fazer a América). Vieram para encontrar a cucagna (a abundância). Assim falava meu nonno Giovani, que aqui chegara, moço ainda, com seus pais e irmãos no fim do século XIX.

Comovida, revi aqueles momentos quando meu nonno, com mil gestos, com voz potente, numa linguagem toda sua, dava a ideia de um quadro surrealista quando contava sobre as dificuldades que tiveram na América; falava das bênçãos e do desânimo, das preces e da saudade, dos experimentos e dos recomeços, das conquistas e do trabalho, que se tornaram a chave para um futuro promissor.

Lembrei-me de que meu nonno ficava com o olhar iluminado ao falar da sua história de vida e de que ele olhava ora para o nada, ora para a parede onde estavam alguns quadros trazidos da Itália. Lembrei também de que nós dois permanecemos, por um tempo, assim calados, um ao lado do outro, analisando 
nossas memórias e mudanças. Logo depois, nos abraçamos, cheios de ternura, multiplicando e dividindo entre nós a força da esperança...

E pensar que nossos antepassados promoveram inúmeras mudanças, dando os primeiros passos em direção ao progresso sem a ajuda da tecnologia. Usaram ferramentas simples, junto com a força e a dedicação, para sobreviverem $e$ progredirem. Suas pequenas ferramentas não foram, por acaso, suas varinhas mágicas? Quem poderá negar isso?

Depois de tantas lembranças, dei-me conta de que a música delicada chegou ao final, e eu sorri.

Hoje, no meu entardecer, ainda me aqueço na igreja. É que eu preciso alimentar-me também de fé para manter o equilíbrio em todos os aspectos da minha vida. Aqueço-me, portando, cantando no coro durante as celebrações litúrgicas.

Na minha casa, onde passo a maior parte do tempo, ocupo-me em cuidar de todos os afazeres domésticos, com a ajuda, é claro, das minhas ajudantes mágicas, porque a mudança também está presente no dia a dia da dona de casa quando ela cozinha, lava, passa, limpa, organiza, questiona, escolhe etc. A mudança, quase sempre, está ligada ao progresso e este é impulsionado por um simples toque de necessidade ou de desejo.

Nas contas do meu tempo, eu penso que, depois de tantos anos da imigração, depois de tanto tempo de laços e traços ítalo-brasileiros, esta cidade é o curriculum vitae de um povo; é seu corpo e sua alma num jeito de compromisso para o desenvolvimento.

\section{CONSIDERAÇÕES FINAIS}

Pode-se dizer que o trabalho a partir dos gêneros textuais, neste caso elaborado com base em uma sequência didática, fornece orientações mais precisas aos alunos sobre os procedimentos a serem realizados em cada etapa da escrita. Além disso, foi possível perceber que os módulos da sequência sistematizam o trabalho e permitem ao professor esclarecer ao aluno, com mais propriedade, sobre aspectos textuais, mostrando, de forma prática, como ocorrem os processos de coesão e de coerência e como eles interferem na construção do sentido do texto. Esse modo de produzir textos mostrou-se, portanto, indispensável para o desenvolvimento de estratégias que podem tornar a produção final mais qualificada, ressignificando, para a aluna, a prática da escrita, a qual, segundo Marcuschi (2001, p. 16), manifesta formalmente os diversos tipos de letramento de um sujeito. De acordo com o autor, escrever é "um bem social indispensável para enfrentar o dia a dia, seja nos centros urbanos ou na zona rural", sendo, portanto, indispensável no que se refere à sobrevivência no mundo moderno. (MARCUSCHI, 2001, p. 16).

Acredita-se ainda que os apontamentos realizados durante o processo de produção do texto foram importantes no sentido de direcionar a aluna para reelaborá-lo, sendo que acreditamos que as informações sobre o que melhorar devem ser claras, sempre explicitando seu porquê.

Durante a escrita da memória literária, também foi possível perceber que a construção de situações que levam o leitor a fazer inferências são interessantes 
recursos de significação, mas precisam estar perfeitamente organizadas para que se obtenham os efeitos de sentido pretendidos.

Além disso, foi gratificante perceber cada progresso da aluna, até ela chegar à versão final do trabalho. Sua postura no processo de rescrita chamou atenção, pois se esforçava ao máximo para expressar suas ideias de modo que o leitor pudesse entendê-la, fazendo adequações, questionando, inserindo novos dados etc. Além do mais, durante a realização do trabalho, a tentativa de agradar ao público ao qual se dirigia servia de estímulo para qualificar cada vez mais a produção. Tratava-se de bancas examinadoras de concursos nacionais e regionais, sendo que, em caso de conseguir a publicação, teria seu texto lido por diversas pessoas. A partir disso, acredita-se que a situação enunciativa proposta (quem escreve, o que escreve, para quem e com que propósito) direcionou a aluna a imaginar seus interlocutores e a compor um texto original e criativo, não somente produzi-lo para ser lido pelo professor. $O$ trabalho resultou em uma Menção Honrosa no Concurso Nacional Rubem Braga, deixando, assim, a aluna e as professoras satisfeitas com a proposta.

Sendo assim, acredita-se que a memória literária produzida se enquadrou em um concepção sociointeracionista de linguagem, entendida como "lugar de inter-ação" entre sujeitos sociais, isto é, de sujeitos ativos, empenhados em uma atividade sociocomunicativa". (KOCH, 2003, p. 41).

Entende-se também que o conhecimento, por parte do professor, do trabalho com os gêneros textuais e com a sequência didática e ainda dos conceitos referentes à textualização e ao sentido do texto, em especial da coesão e da coerência, mostra-se como um modo de ir além das análises que visam apenas à identificação e à classificação de aspectos da língua, em que o texto serve, em muitos casos, apenas como um pretexto para o ensino da gramática normativa. O texto, no estudo de caso apresentado, foi entendido, conforme afirmam os Parâmetros Curriculares Nacionais (1998, p. 78), como instrumento privilegiado de ensino de língua, por ser a "manifestação viva da linguagem".

Enfim, o estudo realizado, envolvendo a escrita e a reescrita do gênero textual memória literária, por meio da sequência didática, sendo observadas também a coesão e a coerência, foi responsável por elucidar conceitos fundamentais para a prática de produção textual em sala de aula. Nesse sentido, acredita-se ser imprescindível que o professor tenha essas noções claras para que elabore estratégias que instrumentalizem seus alunos a produzir textos de forma proficiente, entendendo a escrita como prática social, uma forma de interagir com os outros. Além disso, conforme afirma Antunes (2005), que não chame de falta de coesão e coerência todo e qualquer problema identificado no texto que não se sabe exatamente de que se trata. 


\title{
Writing and rewriting of the literary memory textual genre: strategies for improvement of cohesion and coherence
}

\begin{abstract}
The present article is about a case study that aims to analyze the initial version of a text produced accordingly to the literary memory genre of text, to verify the possibilities of elaboration of strategies that help the improvement of textual cohesion and coherence in the process of rewriting of said text, until the production of a final version, accordingly to proposition of didactic sequence. For such, as main theoretical references Bronckart (2006), Dolz, Noverraz e Schneuwly (2004), Antunes (2005), Koch e Travaglia $(2005,2008)$, Guedes (2009), Koch (2012), among others, will be used. The analysis tried to contribute for production practices of textual genre in formal learning environment, providing resources for the docent to be able to promote situations in a way as to tool its students to produce and rewrite their texts in a way as to observe the subjects of cohesion and coherence. From this study it was possible to perceive that the teacher's work, utilizing text genres, didactic sequences, having as base concepts about textualization and text sense, specially cohesion and coherence, appears as a way to, in Mother Language class, accomplish activities that enhance students abilites.
\end{abstract}

KEYWORDS: Teaching. Genre. Cohesion. Coherence. 


\section{NOTA}

As duas versões da memória literária foram inseridas neste trabalho com a devida autorização da escritora.

\section{REFERÊNCIAS}

ANTUNES, Irandé. Lutar com palavras: a coesão e a coerência. São Paulo: Parábola Editorial, 2005.

BRONCKART, Jean-Paul. Atividade de linguagem, textos e discursos: por um interacionismo sócio-discursivo. Trad. Anna Raquel Machado e Péricles Cunha. São Paulo: EDUC, 2003.

BRONCKART, Jean-Paul. Atividade de linguagem, discurso e desenvolvimento humano. Trad. Anna Raquel Machado e Maria de Lourdes Meirelles Matencio. Campinas, SP: Mercado de Letras, 2006.

BRASIL. Secretaria de Educação Fundamental. Parâmetros Curriculares Nacionais: terceiro e quarto ciclos do Ensino Fundamental. Introdução aos Parâmetros Curriculares Nacionais. Brasília: MEC SEF, 1998.

DOLZ, Joaquim; NOVERRAZ, Michèle; SCHNEUWLY, Bernard. Sequências didáticas para o oral e a escrita: apresentação de um procedimento. In: DOLZ, Joaquim; SCHNEUWLY, Bernard. Gêneros orais e escritos na escola. Trad. Roxane Rojo e Glaís Sales Cordeiro. Campinas: Mercado de Letras, 2004.

GUEDES, Paulo Coimbra. Da redação à produção textual: o ensino da escrita. São Paulo: Parábola Editorial, 2009.

MARCUSCHI, Luís Antônio. Da fala para a escrita: atividades de retextualização. São Paulo: Cortez, 2001.

KOCH, Ingedore Grunfeld Villaça; TRAVAGLIA, Luiz Carlos. A coerência textual. 17. ed. São Paulo: Contexto, 2008.

KOCH, Ingedore Grunfeld Villaça; TRAVAGLIA, Luiz Carlos. Texto e coerência. 10. ed. São Paulo: Cortez, 2005.

$\mathrm{KOCH}$, Ingedore Grunfeld Villaça. A coesão textual. 22. ed. São Paulo: Contexto, 2012. 
KOCH, Ingedore Grunfeld Villaça. Linguística textual e ensino de português. In: TOLDO, Cláudia S. (org.). Questões de linguística. Passo Fundo: UPF, 2003.

KÖCHE, Vanilda Salton; MARINELLO, Adiane Fogalli; BOFF, Odete Maria Benetti. Estudo e produção de textos: gêneros textuais do relatar, narrar e descrever. Petrópolis - RJ: Vozes: 2012.

Como citar: KAODOINSKI, Fabiana; PAVIANI, Neires Maria Soldatelli. Escrita e reescrita do gênero textual memória literária: estratégias para a melhoria da coesão e coerência. R. Letras, Curitiba, v. 19, n. 26, p. 53-75, set. 2017. Disponível em: <https://periodicos.utfpr.edu.br/rl>. Acesso em: XXX.

Direito autoral: Este artigo está licenciado sob os termos da Licença Creative Commons-Atribuição 4.0 Internacional.

\section{(c) (1)}

